\title{
Obligacje komunalne na zorganizowanym rynku kapitałowym
}

\section{Wprowadzenie}

Obligacje komunalne, będące rodzajem komunalnych papierów wartościowych, stanowią instrument finansowania działalności jednostek samorządu terytorialnego (dalej: JST), który na przestrzeni lat uległ pewnym przeobrażeniom. Istotnie zmieniła się też organizacja obrotu obligacjami. Działalność inwestycyjna JST sprzyjała w ostatnich latach dynamicznemu rozwijaniu się rynku kapitałowego, będącego miejscem pozyskiwania środków na finansowanie inwestycji. Przedmiotem niniejszego opracowania jest analiza rozwiązań instytucjonalnych, $\mathrm{w}$ tym regulacji prawnych $\mathrm{w}$ przedmiocie obligacji komunalnych oraz udzielenie odpowiedzi na podstawie przyjętego przez polskiego prawodawcę modelu obrotu obligacjami komunalnymi.

\section{Pojęcie obligacji komunalnych}

Obligacja - zgodnie z art. 4 ust. 1 ustawy z dnia 29 czerwca 1995 r. o obligacjach ${ }^{1}-$ jest papierem wartościowym emitowanym $\mathrm{w}$ serii, $\mathrm{w}$ którym emitent stwierdza, że jest dłużnikiem właściciela obligacji (obligatariusza) i zobowiązuje się wobec niego do spełnienia określonego świadczenia². Świadczenia inkorporowane w obligacjach mogą mieć charakter pieniężny lub niepieniężny. Świadczenie pieniężne obejmuje należność główną (obowiązek wykupu obliga-

* Dr Patrycja Zawadzka - Katedra Prawa Finansowego, Wydział Prawa, Administracji i Ekonomii, Uniwersytet Wrocławski.

${ }^{1}$ T.j. Dz. U. z 2001 r. Nr 120, poz. 1300 ze zm. (dalej: ustawa o obligacjach).

2 Obecnie większość obligacji ma charakter zdematerializowany, a więc stanowią zapis księgowy w pamięci komputera. Obligacja w tradycyjnej postaci fizycznego dokumentu składa się z zapisu dłużnego (tzw. płaszcz) oraz arkusza kuponowego (kuponów bądź ich odcinków, które służą do pobrania odsetek). 
cji) oraz należności uboczne (obowiązek zapłaty odsetek albo sprzedaży obligacji z dyskontem). Oprocentowanie obligacji może mieć charakter stały, zmienny, indeksowany bądź łączny ${ }^{3}$. Świadczenia niepieniężne, jakie mogą wynikać z obligacji, to przede wszystkim prawo do udziału w przyszłych zyskach emitenta, prawo pierwszeństwa do objęcia emitowanych w przyszłości akcji spółki będącej emitentem, prawo do zamiany obligacji na akcje spółki emitującej obligacje oraz prawo do zamiany obligacji na akcje innego podmiotu niż emitent (obligacje wymienne). Świadczenia mogą występować kumulatywnie, tzn. obligacje inkorporują wówczas jednocześnie świadczenie pieniężne i niepieniężne.

Ustawodawca nie określił definicji obligacji komunalnych (municypalnych). Jest to pojęcie doktrynalne, wyodrębnione na podstawie podmiotowego kryterium emitentów obligacji ${ }^{4}$. Zgodnie z dyspozycją art. 2 pkt 2 ustawy o obligacjach obligacje mogą emitować gminy, powiaty, województwa, a także związki tych jednostek oraz miasto stołeczne Warszawa ${ }^{5}$.

W przeciwieństwie do innych emitentów obligacji, JST mogą zobowiązać się do realizacji świadczeń, których możliwość spełnienia jest ściśle powiązana z charakterem emitentów komunalnych - można tu jedynie przykładowo wskazać na możliwości: uzyskania określonych ulg podatkowych przez obligatariuszy; opłacania obligacjami określonych świadczeń lokalnych, takich jak podatki, ceny wykupionych mieszkań komunalnych; uzyskania prawa pierwokupu atrakcyjnych działek stanowiących własność jednostki samorządowej bądź prawo pierwszeństwa w wynajęciu komunalnych lokali użytkowych; uzyskania określonych przywilejów honorowych ${ }^{6}$.

Rodzajem obligacji emitowanych przez JST są obligacje przychodowe. Istotą tych walorów jest sposób spłaty zobowiązania emitenta, tj. uzależnienie od dochodów z konkretnego przedsięwzięcia. Zysk inwestora stanowią środki spłacane wyłącznie z przychodów netto z określonego źródła, które zostało sfinansowane

${ }^{3} \mathrm{O}$ wiele rzadziej występuje oprocentowanie obligacji w formie loteryjnej i premiowej. Obecnie w praktyce polskiego rynku oprocentowanie jest najczęściej oparte na indeksie WIBOR (6M albo 1R). W przeszłości stosowano często oprocentowanie oparte na średniej ważonej stóp rentowności 52-tygodniowych bonów skarbowych oferowanych na przetargach poprzedzających datę ustalenia oprocentowania na następny okres odsetkowy, a także oprocentowanie oparte na indeksie wzrostu cen towarów i usług (np. emisja obligacji Płocka), 13-tygodniowych bonach skarbowych (np. emisja obligacji Mieściska) oraz 26-tygodniowych bonach skarbowych (np. emisja obligacji Jabłonnej).

${ }^{4}$ Szerzej pojęcie obligacji komunalnych omawia m.in.: A. Wacławczyk, Obligacje komunalne, Kraków 2003, s. 22 i n. Por. także: T. Betlej, Obligacje komunalne jako sposób pozyskiwania kapitału, PUG 1997, nr 6, s. 4 i n.; M. Miemiec, Zagadnienia prawne emisji obligacji komunalnych, FK 1996, nr 5, s. 8 i n.; L. Sobolewski, Ustawa o obligacjach. Komentarz, Warszawa 1999; I. Weiss, Obligacje, Warszawa 1997.

${ }^{5}$ Emisje obligacji przeprowadziły m.in. powiaty: gnieźnieński, jarosławski, lubelski, średzki, śląski, wielicki, zgorzelecki oraz województwa: małopolskie, podlaskie i wielkopolskie.

${ }^{6}$ A. Wacławczyk, Obligacje komunalne, Kraków 2003, s. 25-26, cyt. za: S. Bielniak, L. Kałkowski, M. Nowak, T. Włudyka, Przywileje $w$ emisjach papierów wartościowych - pomocnicze materiały dydaktyczne, Kraków 1997. 
w drodze emisji obligacji. Emitent ma obowiązek zawarcia umowy specjalnego rachunku bankowego, na który po zrealizowaniu przedsięwzięcia wpływają środki ze sprzedaży usług, a z którego następnie dokonywane są wypłaty. Jednostka nie może dokonywać wypłat środków z takiego rachunku dla celów innych niż zaspokojenie roszczeń obligatariuszy. Emitentami obligacji przychodowych mogą być: jednostka samorządu terytorialnego, związek jednostek samorządu terytorialnego, miasto stołeczne Warszawa (art. 23a ust. 1 pkt 1 ustawy o obligacjach) ${ }^{7}$.

Warto zasygnalizować, że oprócz obligacji komunalnych formą pośredniego uczestnictwa JST na rynku kapitałowym jest emisja akcji spółek komunalnych ${ }^{8}$. Ponadto, JST może występować w roli inwestora.

\section{Pozytywne i negatywne aspekty emisji obligacji komunalnych}

Wybór emisji obligacji komunalnych jako instrumentu pozyskiwania zewnętrznego finansowania powinien być poprzedzony szczegółową analizą jej zasadności przez pryzmat pozytywnych i negatywnych aspektów in concreto. Emisja obligacji w porównaniu do kredytu bankowego ma tę zaletę, że to JST przy uwzględnieniu obowiązujących przepisów prawa - indywidualnie ustala większość warunków emisji, takich jak m.in. terminy emisji, liczba transzy oraz warunki spłaty. Emisja obligacji komunalnych umożliwia pozyskanie środków na dłuższy czas aniżeli umowa kredytu. W przypadku obligacji podmiot zacią-

${ }^{7}$ Pierwszą w Polsce oraz w Europie Środkowej emisję obligacji przychodowych przeprowadziło konsorcjum banków Pekao i Citibanku Handlowego dla miejskich Wodociągów i Kanalizacji w Bydgoszczy. Środki były wykorzystane na rozbudowę infrastruktury miejskiej, m.in. renowację systemu wodociągowego. Szerzej o obligacjach przychodowych np.: M. Bitner, Obligacje przychodowe, PPW 2001, nr 5; M. Jastrzębska, Zarządzanie dlugiem jednostek samorzadu terytorialnego, Warszawa 2009, s. 59-68.

${ }^{8}$ Zagadnienie dopuszczalności lokowania przez gminy własnych środków pieniężnych, to jest nabywania i zbywania akcji, budziło istotne wątpliwości wobec regulacji zarówno art. 9 ust. 2 , jak i art. 50 ustawy o samorządzie terytorialnym. Do nabywania akcji na rynku giełdowym przez zarząd gminy pozytywnie odniósł się NSA, stwierdzając, iż „uchwała rady gminy, upoważniająca zarząd gminy do nabywania i zbywania akcji na giełdzie papierów wartościowych w granicach kwot określonych w uchwale budżetowej, nie może być oceniana jako naruszająca przepis art. 50 ustawy z dnia 8 marca 1990 r. o samorządzie terytorialnym (Dz. U. Nr 16, poz. 95 ze zm.) tylko na tej zasadzie, że operacje giełdowe połączone są z określonym stopniem ryzyka" (wyrok NSA z dnia 17 maja 1995 r., SA/Wr 275/95, ONSA 1996, nr 3, poz. 113). Obrót tytułami uczestnictwa w spółkach nie wypełnia znamion działalności gospodarczej (wyrok SN z dnia 14 marca 1995 r., III CZP 6/95, OSN 1995, nr 5, poz. 72). Wyrażone zostało również stanowisko, że udział kapitałowy gminy w banku działającym w formie spółki akcyjnej nie jest prowadzeniem działalności gospodarczej w rozumieniu art. 9 ust. 2 ustawy o samorządzie terytorialnym (uchwała składu siedmiu sędziów SN z dnia 14 marca 1995 r. II CZP 7/95, niepubl.). Pogląd ten zakłada dopuszczalność nabywania przez gminę akcji w spółce akcyjnej i zbywania tych akcji.

${ }^{9}$ Obecnie popularne są obligacje komunalne z 7-10-letnim okresem zapadalności. Jednostki samorządu terytorialnego rzadziej emitują obligacje z kilkunastoletnim okresem wykupu. 
gający dług (emitent) nie ponosi kosztów prowizji pobieranej przy zaciągnięciu kredytu oraz nie jest kontrolowany co do sposobu wykorzystania środków pochodzących ze sprzedaży obligacji. Do sprzedaży obligacji nie stosuje się ustawy z dnia 29 stycznia 2004 r. Prawo zamówień publicznych ${ }^{10}$.

Obligacje stanowią instrument finansowy, który umożliwia pozyskanie środków na przedsięwzięcia inwestycyjne, które nie mogą być w całości sfinansowane z budżetu JST. Jest to forma alternatywna względem umowy kredytu czy bezzwrotnych środków publicznych, o których mowa w art. 5 ust. 1 pkt 2 i 3 ustawy z dnia 27 sierpnia 2009 r. o finansach publicznych ${ }^{11}$. Przy dużej wielkości emisji koszty są niższe w porównaniu z kredytem bankowym, biorąc pod uwagę kwotę zobowiązania, okres spłaty, sposób rozłożenia płatności, ewentualną karencję w spłacie. Wysoce korzystnie dla JST przedstawia się brak zabezpieczeń emisji. Emisja nie wymaga ustanowienia szczególnego zabezpieczenia, np. w postaci wpisu hipoteki do księgi wieczystej na nieruchomości JST.

Emisje publiczne są bardzo popularne, m.in. ze względu na efekt marketingowy. Jednostka dokonująca emisji jest odbierana jako podmiot korzystający z nowoczesnych instrumentów zarządzania finansami.

Zaletą omawianej formy jest możliwość rozłożenia spłat rat nawet na okres 15-20 lat oraz zastrzeżenie w warunkach emisji wcześniejszego wykupu obligacji. Ujemną stroną emisji obligacji dla JST może być trudność z ich sprzedażą, a tym samym niepewność co do ilości środków zebranych wskutek emisji. Wadą obligacji jest możliwość zaistnienia konieczności wykupu obligacji przez emitenta bez względu na jego bieżącą kondycję finansową w określonym terminie, który został zaplanowany kilka lat wcześniej przy emisji obligacji.

Cechą szczególną obligacji komunalnych jest konieczność oznaczenia celu emisji. Jednostka nie może przeznaczyć środków pochodzących z emisji obligacji na inne cele (art. 28 ust. 1 i 3 ustawy o obligacjach). Pewne ograniczenia wynikają z u.f.p. - m.in. w zakresie celu emisji (art. 89 u.f.p.), dopuszczalnych limitów zadłużenia obowiązku oraz uwzględnienia $\mathrm{w}$ wieloletniej prognozie finansowej (dalej: w.p.f.). Pozytywnym aspektem dla JST jest możliwość niedookreślenia celów emisji, np. ogólnie pojęta infrastruktura komunalna albo wskazanie kilku celów inwestycyjnych równocześnie.

Emitent odpowiada całym swoim majątkiem za zobowiązania wynikające z obligacji, z wyjątkami dotyczącymi emisji obligacji przychodowych. Skutek ekonomiczny emisji obligacji komunalnych jest zatem pod tym względem analogiczny do umowy kredytu czy umowy pożyczki.

Niezbędne i bardzo doniosłe znaczenie w praktyce ma dokonanie tzw. analizy scenariuszowej polegającej na uwzględnieniu granic zaciągania zobowiązań oraz wskazania potencjalnych zagrożeń $\mathrm{w}$ zakresie planowanych środków

10 T.j. Dz. U. z 2007 r. Nr 223, poz. 1655 ze zm. (dalej: p.z.p.).

${ }^{11}$ Dz. U. Nr 157, poz. 1240 ze zm. (dalej: u.f.p.). 
publicznych w w.p.f. ${ }^{12}$ Realizacja zadań inwestycyjnych przez JST wiąże się ze zwiększonym zapotrzebowaniem na środki finansowe. W kontekście emisji obligacji komunalnych należy szczegółowo przeanalizować czynniki ryzyka związane z działalnością JST, które będą następnie zawarte w dokumencie informacyjnym. Chodzi przede wszystkim o ryzyko pogorszenia sytuacji samorządów na skutek zwiększenia ich zadań. Zaplanowane przez JST środki na realizację określonego zadania mogą okazać się niewystarczające w stosunku do faktycznych potrzeb, jakie pojawią się w perspektywie kilku lat od dnia emisji. W konsekwencji JST może zostać zmuszona do finansowania nowych zadań kosztem ograniczenia innych wydatków lub do zaciągnięcia dodatkowych zobowiązań. Nie można wykluczyć również ryzyka zmiany przepisów prawa, mającej bezpośredni wpływ na kształtowanie się zaplanowanego w prognozie finansowej poziomu dochodów JST. Ponadto, jeżeli część zadań realizowanych przez JST ma być finansowana ze źródeł zewnętrznych o charakterze zwrotnym (kredyty, pożyczki, obligacje) lub bezzwrotnym (np. środki z funduszy UE), istnieje ryzyko, że jednostka nie otrzyma dofinansowania na dane zadanie, co spowoduje niemożność jego realizacji albo potrzebę zwiększenia zadłużenia. Warto podnieść także kwestię, iż dochody JST w istotnej mierze pochodzą z podatków i opłat lokalnych oraz udziału w podatku dochodowym od osób fizycznych i podatku dochodowego od osób prawnych, co np. w sytuacji spowolnienia gospodarczego może znaleźć odzwierciedlenie w dochodach budżetowych. Należy także wskazać na ryzyko płynności obligacji - nie można zagwarantować, że pomimo wprowadzenia obligacji do oferty publicznej, będzie występować zadowalająca płynność walorów ${ }^{13}$.

\section{Prawne podstawy emisji i organizacji rynku zorganizowanego}

Podstawy prawne zorganizowanego (dawniej „publicznego”) obrotu obligacjami stanowi ustawa z dnia 29 lipca 2005 r. o obrocie instrumentami finansowymi ${ }^{14}$ oraz ustawa $\mathrm{z}$ dnia 29 lipca $2005 \mathrm{r}$. o ofercie publicznej i warunkach wprowadzania instrumentów finansowych do zorganizowanego systemu obrotu oraz o spółkach publicznych ${ }^{15}$. Obrotem zorganizowanym jest obrót papierami wartościowymi lub innymi instrumentami finansowymi dokonywany na terytorium Rzeczypospolitej Polskiej na rynku regulowanym albo w alternatywnym sys-

${ }^{12}$ Przy czym wyznaczanie poza okres czteroletni jest ryzykowne, a trzeba pamiętać, że uchwała o w.p.f. powinna być realistyczna. P. Zawadzka, Konsekwencje prawne przekroczenia przez jst indywidualnego wskaźnika zadlużenia określonego w art. 243 u.f.p., „Prawo finansów publicznych” 2012, nr 3, s. 11.

${ }^{13}$ Szersze omówienie rodzajów ryzyka wykracza poza ramy tego artykułu i zostało pominięte.

${ }_{14}$ T.j. Dz. U. z 2010 r. Nr 211, poz. 1384 ze zm. (dalej: u.o.i.f.).

15 T.j. Dz. U. z 2009 r. Nr 185, poz. 1439 ze zm. (dalej: u.o.p.). 
temie obrotu (art. 3 pkt 9 u.o.i.f.). Na rynku regulowanym ma on miejsce na rynku giełdowym organizowanym przez Giełdę Papierów Wartościowych w Warszawie S.A. oraz na rynku pozagiełdowym organizowanym przez BondSpot S.A. Do dnia 18 września 2009 r. rynek pozagiełdowy był organizowany przez MTS-CeTO S.A., a od 6 grudnia 1996 r. do maja 2004 r. przez Centralną Tabelę Ofert S.A. regulowany rynek pozagiełdowy CeTO. Na rynku pozagiełdowym CeTO dokonywano emisji obligacji komunalnych oraz przedsiębiorstw komunalnych (w tym m.in. Holikom S.A. z siedzibą w Ostrowie Wielkopolskim oraz AQUA S.A. z siedzibą w Bielsko-Białej) ${ }^{16}$. Jako pierwsze emisje obligacji komunalnych notowanych na rynku regulowanym CeTO wskazuje się emisje obligacji komunalnych miast: Ostrowa Wielkopolskiego, Rybnika i Poznania; przy czym emisje pierwszego z miast były emisjami niepublicznymi, a dopiero później zostały wprowadzone do obrotu publicznego ${ }^{17}$. Przeprowadzona w 2002 r. emisja obligacji komunalnych miasta Rybnik była pierwszą w Polsce emisją o charakterze publicznym.

Od dnia 30 września 2009 roku, tj. rozpoczęcia działalności przez Rynek Obligacji Catalyst, pełni on najważniejszą rolę w zakresie zorganizowanego obrotu obligacjami komunalnymi. Przed utworzeniem Rynku Obligacji Catalyst w przeważającej mierze obligacje komunalne były nabywane na własny rachunek przez jednego inwestora, np. bank będący agentem emisji ${ }^{18}$, a zatem większość emisji obligacji komunalnych miała charakter niepubliczny. Emisje zamknięte swym charakterem ekonomicznym są zbliżone do kredytu. Na korzyść obligacji przemawia jednak elastyczność w zakresie możliwych transzy pozyskiwania i spłacania środków oraz ewentualna karencja spłaty.

Rynek obligacji Catalyst zbudowany jest z czterech platform obrotu. Dwie prowadzone przez GPW - w formule rynku regulowanego i alternatywnego systemu obrotu ${ }^{19}$. Jest to segment detaliczny, gdzie jednostką transakcyjną jest jedna obligacja. Analogiczne dwie platformy BondSpotu (regulowany i ASO) tworzą segment hurtowy, a jednostka transakcyjna ma wartość co najmniej 100 tys. zł.

16 Należy pamiętać, iż zgodnie z dyspozycją art. 1 ust. 2 ustawy z dnia 20 grudnia 1996 r. o gospodarce komunalnej (t.j. Dz. U. z 2011 r. Nr 45, poz. 236) gospodarka komunalna obejmuje w szczególności zadania o charakterze użyteczności publicznej, których celem jest bieżące i nieprzerwane zaspokajanie zbiorowych potrzeb ludności w drodze świadczenia usług powszechnie dostępnych. Przedsiębiorstwa takie zatem ipso iure nie mogą dążyć do maksymalizacji zysku. Ewentualny wzrost aktywów jest stabilny. Działalność w sferze użyteczności publicznej zapewnia, poprzez swego rodzaju monopol, że nie spadnie zapotrzebowanie na ich usługi.

17 S. Huczek, Komunalne papiery wartościowe na rynku regulowanym, FK 2007, nr 4, s. 18 i cyt. za: A. Babczuk, A. Janusz, Obligacje municypalne jako obszar wspótpracy jednostek samorzadu terytorialnego z bankami - teoria i praktyka, [w:] S. Dolata (red.), Prawne i finansowe aspekty finansowania samorzadu terytorialnego, Opole 2000, s. 460.

18 Agent emisji był zobligowany do prowadzenia rejestru obligacji, o którym mowa w art. 5a ust. 3 ustawy o obligacjach. Spoczywał na nim także obowiązek wypłaty świadczeń związanych z obligacjami, tj. odsetek oraz ich wykupu. W ramach Catalyst dokonuje tego KDPW.

19 Normatywna definicja alternatywnego systemu obrotu została zawarta w art. 3 pkt 2 u.o.i.f. 
Poza obligacjami komunalnymi na Rynku Obligacji Catalyst obrót dokonywany jest nieskarbowymi instrumentami dłużnymi, takimi jak obligacje korporacyjne i listy zastawne. Z punktu widzenia JST segmenty hurtowy i detaliczny różnią się przede wszystkim kryteriami dopuszczania na rynek oraz zakresem obowiązków informacyjnych.

\section{Rodzaje emisji obligacji komunalnych}

De lege lata istnieją dwa rodzaje emisji obligacji komunalnych - oferta prywatna (niepubliczna) oraz oferta publiczna (obrót zorganizowany). Oferta prywatna polega na skierowaniu indywidualnych ofert do kręgu nie więcej niż 99 osób (a contrario art. 3 ust. 3 u.o.p.) i w dotychczasowej praktyce sprowadzała się do nabycia obligacji przez bank. Istnieje także możliwość przekształcenia dokonanej emisji niepublicznej, skierowanej do konkretnego inwestora (obligatariusza) i następnie wprowadzenia walorów do obrotu publicznego ${ }^{20}$.

Ofertą publiczną jest udostępnianie, co najmniej 100 osobom lub nieoznaczonemu adresatowi, w dowolnej formie i w dowolny sposób ${ }^{21}$, informacji o papierach wartościowych i warunkach dotyczących ich nabycia, stanowiących dostateczną podstawę do podjęcia decyzji o odpłatnym nabyciu tych papierów wartościowych (art. 3 ust. 3 u.o.p. $)^{22}$.

Emisja obligacji wymaga podjęcia uchwały przez organ stanowiący JST w zakresie upoważnienia zarządu do zbadania możliwości emisji obligacji, którego udzielenie powinno być poprzedzone rzetelną analizą możliwości dokonania emisji, w szczególności w kontekście budżetu i w.p.f. Drugim krokiem jest podjęcie przez organ stanowiący uchwały w sprawie emisji obligacji, określenia celu oraz zasad zbywania i wykupu. Uchwała ta, na podstawie art. 11 ust. 1 pkt 3 ustawy z dnia 7 października 1992 r. o regionalnych izbach obrachunkowych ${ }^{23}$, podlega zaopiniowaniu przez organ nadzoru w zakresie zgodności z prawem. Ponadto, na podstawie art. 13 pkt $1 \mathrm{i}$ art. 19 ust. 2, zaopiniowaniu przez skład orzekający regionalnej izby obrachunkowej podlega możliwość wykupu obligacji. Trzeci etap stanowi wybór agenta emisji ${ }^{24}$. Czwarty etap to sprzedaż obligacji, tzw.

${ }^{20}$ Emisje takie przeprowadziły m.in.: Ostrów Wielkopolski, Zamość, Radlin.

${ }^{21}$ Publiczny charakter oferty ma miejsce wtedy, gdy oferta adresowana jest do wszystkich, a nie tylko do ograniczonego kręgu adresatów. Zob. wyrok WSA w Warszawie z 24 stycznia 2007 r., III SA/Wa 3928/06, niepubl., a także wyrok NSA w Warszawie z 2 grudnia 2005 r., FSK 2626/04, niepubl.

${ }^{22}$ Oferta nie jest jeszcze obrotem, a zaledwie propozycją zawarcia umowy (wyrok WSA w Warszawie z 2 marca 2007 r., III SA/Wa, niepubl. oraz wyrok WSA w Gdańsku z 4 stycznia 2007 r., I SA/Gd 838/06, niepubl.).

${ }^{23}$ T.j. Dz. U. z 2001 r. Nr 55, poz. 577 ze zm. (dalej: u.r.i.o.).

${ }^{24} \mathrm{Na}$ podstawie art. 4 pkt 3 lit. j p.z.p. przepisów ustawy Prawo zamówień publicznych nie stosuje się do ,usług finansowych związanych z emisją, sprzedażą, kupnem lub transferem papierów 
plasowanie emisji, polegające na skierowaniu propozycji nabycia do konkretnego adresata (emisja prywatna) albo nieograniczonego kręgu inwestorów (emisja publiczna), gdzie pozyskiwanie środków następuje po przeprowadzeniu procedury wprowadzenia obligacji na rynek.

Przyjęcie oferty nabycia przez konkretnego adresata następuje w drodze wypełnienia stosownego formularza wskazującego na oświadczenie woli oraz po dokonaniu wpłaty środków przez obligatariusza na rachunek bankowy emitenta. W sytuacji zdematerializowanych walorów są one zapisywane w odpowiednim rejestrze na rachunku papierów wartościowych inwestora. Jeżeli dochodzi do emisji w tradycyjnej formie fizycznego dokumentu, to następuje wydanie obligacji obligatariuszowi.

Emisja w drodze otwartej subskrybcji bez udziału subemitenta polega na nabywaniu walorów przez inwestorów bezpośrednio w firmie inwestycyjnej ${ }^{25}$. Emisja może także nastąpić przy udziale subemitenta. Subemisja inwestycyjna jest to umowa zawierana przez emitenta (ewentualnie wprowadzającego), której przedmiotem jest zobowiązanie subemitenta inwestycyjnego do nabycia na własny rachunek całości lub części papierów wartościowych oferowanych w obrocie pierwotnym lub w pierwszej ofercie publicznej, na które nie złożono zapisów w terminie ich przyjmowania ${ }^{26}$ (zob. art. 4 pkt 12 oraz 14 ustawy o ofercie publicznej ${ }^{27}$ ). Przedmiotem umowy o subemisję usługową jest zaś zobowiązanie subemitenta usługowego względem emitenta (albo wprowadzającego) do nabycia na własny rachunek całości lub części papierów wartościowych danej emisji $\mathrm{w}$ celu dalszego ich zbywania w obrocie pierwotnym lub w pierwszej ofercie publicznej ${ }^{28}$.

Obrót obligacjami na Rynku Obligacji Catalyst wymaga rejestracji w Krajowym Depozycie Papierów Wartościowych (KDPW). Krajowy Depozyt oprócz prowadzenia ewidencji papierów wartościowych obsługuje również wykup

wartościowych lub innych instrumentów finansowych, w szczególności związanych z transakcjami mającymi na celu uzyskanie dla zamawiającego środków pieniężnych lub kapitału. Przy wyborze agenta emisji problematycznie kształtowałoby się opracowanie kryteriów wyboru, zwłaszcza kryterium związanego z oceną doświadczenia i wiarygodności oferenta, czy też analizą rzeczywistych kosztów zadłużenia (tzw. wewnętrznej stopy zwrotu - ang. Internal Rate of Return (IRR))".

${ }^{25}$ Pierwszej takiej emisji dokonał Poznań (2003 r.; następnie powtórzono ją w 2006 r.).

${ }^{26}$ M. Kuźnicka, M. Marczuk, [w:] M. Wierzbowski, L. Sobolewski, P. Wajda (red.), Prawo rynku kapitałowego. Komentarz, Warszawa 2012, s. 62.

${ }^{27}$ Ustawa z dnia 29 lipca 2005 r. o ofercie publicznej i warunkach wprowadzania instrumentów finansowych do zorganizowanego obrotu oraz o spółkach publicznych (t.j. Dz. U. z 2009 r. Nr 185, poz. 1439 ze zm.; dalej: ustawa o ofercie publicznej).

${ }_{28}$ A. Chłopecki, [w:] A. Chłopecki, M. Dyl, Prawo rynku kapitałowego, Warszawa 2011, s. 73. Umowy subemisji funkcjonują w praktyce obrotu także pod nazwą gwarancji emisji lub anglojęzycznym terminem underwriting. Zob. A. W. Wiśniewski, Wybrane problemy tak zwanej gwarancji emisji, „Glosa” 1995, nr 12; E. Frankowski, Gwarantowanie emisji w prawie amerykańskim i polskim, PPH 2003, nr 2; M. Romanowski, Prawo o publicznym obrocie papierami wartościowymi. Komentarz, Warszawa 1999, s. 133. 
i wypłatę odsetek. Rejestracja emisji w KDPW wiąże się ze złożeniem stosownego wniosku wraz z załącznikami, wśród których jest m.in. uchwała w sprawie emisji oraz tzw. list księgowy obligacji zawierający najważniejsze informacje o obligacjach. Jednostka, będąca emitentem, zawiera umowę, na podstawie której obligacjom nadawany jest indywidualny kod. Jednostka staje się na podstawie zawartej umowy uczestnikiem bezpośrednim KDPW.

Przy obrocie wtórnym obligacjami na Rynku Obligacji Catalyst konieczne jest zawarcie z firmą inwestycyjną umowy, na podstawie której firma będzie tzw. agentem emisji ${ }^{29}$. Przedmiotem tej umowy jest pośrednictwo w sprzedaży walorów na rynku ${ }^{30}, \mathrm{w}$ tym dokonywanie tzw. rozksięgowania obligacji zapisanych na rachunku agenta emisji przez KDPW na rachunki imienne inwestorów (obligatariuszy), którzy nabyli obligacje w ofercie pierwotnej. Agent emisji podpisuje list księgowy obligacji, który jest składany w KDPW.

Wprowadzenie na Catalyst może być przeprowadzone w dwojaki sposób: poprzez uzyskanie autoryzacji Catalyst albo w drodze skierowania emisji do obrotu zorganizowanego na rynku regulowanym lub w alternatywnym systemie obrotu.

W ramach oferty publicznej JST nie ma obowiązku sporządzania prospektu lub memorandum informacyjnego (art. 7 ust. 2 pkt 2 u.o.p. oraz art. 42 u.o.p.), a zatem procedura przed KNF w przedmiocie wprowadzania do obrotu obligacji komunalnych została zdecydowanie uproszczona. Wprowadzenie obligacji komunalnych do obrotu na Catalyst (na rynku regulowanym i w alternatywnym systemie obrotu) wymaga sporządzenia dokumentu informacyjnego przez autoryzowanego doradcę ${ }^{31}$. Wprowadzenie instrumentów finansowych do obrotu w alternatywnym systemie obrotu nie stanowi dopuszczenia ani wprowadzenia tych instrumentów do obrotu na rynku giełdowym. Dokument informacyjny nie jest zatwierdzany pod względem zgodności informacji w nim zawartych ze stanem faktycznym lub przepisami prawa przez organ nadzoru (KNF) ani przez organizatora obrotu. Podmiotem odpowiedzialnym za informacje zawarte w dokumencie informacyjnym jest sama JST będąca emitentem ${ }^{32}$.

Warto zauważyć, iż dla JST standard przygotowywania dokumentu informacyjnego został znacznie uproszczony. Dokument ten zawiera podstawowe infor-

${ }^{29} \mathrm{Tu}$ pojęcie agenta emisji nabiera innego niż tradycyjne znaczenia.

${ }^{30}$ Charakter prawny omawia m.in. K. Zacharzewski, Umowa o pośrednictwo giełdowe, Toruń 2008, s. 158 i n.

${ }^{31}$ Zakres działań autoryzowanego doradcy obejmuje: sporządzenie dokumentu informacyjnego, współpracę z JST w wypełnianiu obowiązków informacyjnych, bieżące doradztwo JST w zakresie dotyczącym funkcjonowania obligacji komunalnych w alternatywnym systemie obrotu.

32 Por. zakres odpowiedzialności za informacje zamieszczone w prospekcie informacyjnym. $\mathrm{Z}$ dokumentu informacyjnego nie można wykluczyć art. 22 ust. 4 u.o.p., który stanowi, iż za prawdziwość, rzetelność i kompletność informacji zamieszczonych w prospekcie emisyjnym odpowiadają liczne osoby, chociaż każda z nich w różnym zakresie. 
macje o JST oraz danej emisji obligacji ${ }^{33}$. W ramach rynku obligacji opracowany został Rekomendowany standard konstrukcji obligacji korporacyjnych $i$ samorzqdowych ${ }^{34}$.

Przy wprowadzeniu obligacji na Rynek Obligacji Catalyst wyłącznie dla uzyskania autoryzacji nie stosuje się rejestracji obligacji w KDPW. Wymóg dematerializacji nie obowiązuje, jednak ze względów praktycznych warto jej dokonaćs ${ }^{35}$. Uzyskanie autoryzacji Catalyst wymaga, aby walorom emitenta został nadany przez KDPW kod ISIN oraz CFI, co jest niezbędne nawet w przypadku, gdy papiery wartościowe nie są zdematerializowane. Kody są przyznawane emitentowi po podpisaniu umowy, na podstawie wniosku (lub wniosków, jeżeli emitent chce uzyskać kod dla kilku serii). Procedura nadawania kodów obligacjom JST jest krótsza niż rejestracja innych instrumentów finansowych w KDPW. Dokumenty (wnioski oraz umowa) powinny być podpisane przez burmistrza oraz kontrasygnowane przez skarbnika. Podobnie należy postąpić w przypadku wniosków składanych do organizatora rynku o dopuszczenie lub wprowadzenie do obrotu.

$\mathrm{Na}$ koniec 2009 r. na rynku giełdowym znajdowało się 51 serii obligacji, w tym 3 serie obligacji komunalnych ${ }^{36}$. Na Rynku Obligacji Catalyst na koniec 2009 r. emitowanych było 9 serii obligacji komunalnych ( 9 emitentów) o wartości emisji $930 \mathrm{mln}$ zł; na koniec 2010 r. - 27 serii (16 emitentów) o wartości emisji 1753 mln zł; na koniec 2011 r. - 24 serie obligacji (11 emitentów) o wartości emisji $2222 \mathrm{mln} \mathrm{z}^{37}$.

\section{Podsumowanie}

Zarządzanie JST powinno być ukierunkowane na optymalne zaspokojenie potrzeb mieszkańców, w tym na rozwój infrastruktury. Wśród czynników wyboru zewnętrznych źródeł finansowania inwestycji można wymienić dostęp do określonej formy kapitału, warunki, procedury jego pozyskania oraz elastyczność zarządzania długiem. Niezaprzeczalną korzyścią emisji obligacji na rynku regulowanym jest przejrzystość rynku związana z obowiązkami informacyjnymi, zwiększona płynność walorów oraz - mająca istotne znaczenie dla inwestorów - możliwość równoczesnego dostępu do informacji. Obligacje komunalne

33 Emitenci, których instrumenty finansowe już są notowane, nie mają obowiązku sporządzania dokumentu informacyjnego, a jedynie krótkiej noty informacyjnej.

34 Źródło: http://gpwcatalyst.pl/pub/files/materialy_do_pobrania/catalyst_standard_obligacji _euro.pdf (dostęp: 30.06.2012).

35 Zob. § 6 Zasady Działania Catalyst: www.gpwcatalyst.pl/pub/files/materialy_do_pobrania/ Zasady_Dzialania_Catalyst_04.11.2010.pdf (dostęp: 30.06.2012).

36 Wszystkie obligacje notowane były w systemie notowań ciągłych. Źródło: Rocznik Giełdowy 2010, Giełda Papierów Wartościowych w Warszawie S.A., Warszawa 2010, s. 74.

37 Źródło: http://gpwcatalyst.pl (dostęp: 30.06.2012). 
przynoszą niewątpliwie efekt marketingowy. Jednostka jest postrzegana jako podmiot korzystający z nowoczesnych form finansowania inwestycji, co zwiększa jej wiarygodność. Jak wskazuje praktyka rynku, ułatwia to pozyskanie środków z rynku kapitałowego w przyszłości.

Do atrakcyjności obligacji komunalnych jako formy finansowania przedsięwzięć przyczynia się niewątpliwie możliwość indywidualnego ustalenia przez JST harmonogramu spłaty kapitału. Harmonogramu nie ustala bank, jak ma to miejsce przy umowie kredytu, co daje sposobność do dogodnego dopasowania terminów pozyskiwania środków poprzez odpowiedni podział emisji na serie i transze. Zaletą jest długi okres karencji w spłacie kapitału (np. 5-7 lat), co umożliwia dopasowanie spłat do sytuacji finansowej JST oraz względnie niskie koszty obsługi oparte na stawce WIBOR. Oczywiście każdorazowo emisja musi być odpowiednio zaplanowana $\mathrm{w}$ budżecie i w.p.f. oraz poprzedzona rzetelną analizą w przedmiocie zasadności wyboru tego instrumentu zewnętrznego finansowania.

Istotnym momentem, który przyczynił się do bardziej dynamicznego rozwoju obligacji komunalnych jako formy finansowania inwestycji oraz deficytu JST, było utworzenie z dniem 30 września 2009 r. Rynku Obligacji Catalyst. Przed jego powstaniem większość emisji obligacji samorządowych w Polsce miała charakter emisji niepublicznych. Stworzenie rynku obligacji Catalyst ustanowiło zatem nową jakość na polskim rynku kapitałowym. Całokształt rozwiązań prawnych, w tym instytucjonalnych, dotyczących obligacji komunalnych na zorganizowanym rynku kapitałowym $\mathrm{w}$ chwili obecnej wydaje się odpowiadający sytuacji rynkowej. Rynek jest dostosowany do emisji o różnych wielkościach i różnej charakterystyce, a także do potrzeb różnych inwestorów - hurtowych i detalicznych, instytucjonalnych i indywidualnych. Istotne jest, aby środki pozyskane z emisji obligacji komunalnych były przekazywane na inwestycje, a nie tylko na pokrycie deficytu, wynikającego z niegospodarności JST. 